\title{
Zero carbon energy system of South East Europe in 2050
}

\author{
D.F. Dominković a,*, I. Bačeković ${ }^{b}$, B. Ćosić ${ }^{c}$, G. Krajačic ${ }^{c}$, T. Pukšec $^{c}$, N. Duić ${ }^{c}$, N. Markovska ${ }^{d}$ \\ ${ }^{a}$ Technical University of Denmark, Department of Energy Conversion and Storage, Frederiksborgvej 399, Roskilde, Denmark \\ ${ }^{\mathrm{b}}$ Aalborg University, Aalborg, Denmark \\ ${ }^{\mathrm{c}}$ Faculty of Mechanical Engineering and Naval Architecture, University of Zagreb, Zagreb, Croatia \\ ${ }^{\mathrm{d}}$ Macedonian Academy of Sciences and Arts, Skopje, Macedonia
}

\section{H I G H L I G H T S}

- $100 \%$ renewable energy system of the South East Europe has been achieved.

- Sector integration makes the zero carbon system cheaper compared to the base year.

- Numerous renewable technologies needed to achieve zero carbon in the year 2050.

- Energy efficiency is a crucial part in a transition to the zero carbon energy system.

- No technology has a larger share than 30\%; increased security of energy supply.

\section{A R T I C L E I N F O}

\section{Article history:}

Received 23 November 2015

Received in revised form 26 February 2016

Accepted 14 March 2016

Available online 19 March 2016

\section{Keywords:}

Smart energy system

Renewable energy system

Zero carbon

South East Europe

Sustainable biomass

Energy efficiency

\begin{abstract}
A B S T R A C T
South East Europe is the region in a part of Europe with approximately 65.5 million inhabitants, making up $8.9 \%$ of Europe's total population. The countries concerned have distinct geographical features, various climates and significant differences in gross domestic product per capita, so the integration of their energy systems is considered to be a challenging task. Large differences between energy mixes, still largely dominated by fossil-fuel consumption, make this task even more demanding.

This paper presents the transition steps to a $100 \%$ renewable energy system which need to be carried out until the year 2050 in order to achieve zero carbon energy society. Novelty of this paper compared to other papers with similar research goals is the assumed sustainable use of biomass in the $100 \%$ renewable energy system of the region considered. It is important to emphasize here that only the sustainable use of biomass can be considered carbon-neutral. The resulting biomass consumption of the model was 725.94 PJ for the entire region, which is in line with the biomass potential of the region. Modelling the zero-carbon energy system was carried out using the smart energy system concept, together with its main integration pillars, i.e. power-to-heat and power-to-gas technologies. The resulting power generation mix shows that a wide variety of energy sources need to be utilized and no single energy source has more than a $30 \%$ share, which also increases the security of supply. Wind turbines and photovoltaics are the main technologies with shares of $28.9 \%$ and $22.5 \%$, followed by hydro power, concentrated solar power, biomass (mainly used in cogeneration units) and geothermal energy sources. To keep the biomass consumption within the sustainability limits, there is a need for some type of synthetic fuel in the transportation sector. Nevertheless, achieving $100 \%$ renewable energy system also promises to be financially beneficial, as the total calculated annual socio-economic cost of the region is approximately 20 billion euros lower in the year 2050 than in the base year. Finally, energy efficiency measures will play an important role in the transition to the zero-carbon energy society: the model shows that primary energy supply will be $50.9 \%$ lower than in the base year.
\end{abstract}

() 2016 Elsevier Ltd. All rights reserved.

\footnotetext{
* Corresponding author.

E-mail addresses: dodo@dtu.dk (D.F. Dominković), ibacekovic@gmail.com (I. Bačeković), boris.cosic@fsb.hr (B. Ćosić), goran.krajacic@fsb.hr (G. Krajačić), tomislav.puksec@fsb.hr (T. Pukšec),neven.duic@fsb.hr (N. Duić), natasa@manu.edu. mk (N. Markovska).
}

\section{Introduction}

Countries in the South East Europe (SEE) region have been facing various common problems related to the energy sectors. Energy markets are generally small and energy prices are below economic level, while countries' economies are energy intensive. 
Furthermore, tariff structures are undeveloped and poor infrastructure as well as history of conflicts complicate energy trade in the region [1]. Therefore, regional cooperation of the SEE countries, integration of energy systems and harmonization of legislations is necessary. In order to increase security of supply, economic efficiency and use of renewable energy sources (RES), which are important for future energy systems, as well as to reduce market concentration, common energy system has to be created [2]. Nevertheless, transition to clean renewable energy systems can be beneficial in economic, energy-environmental and sociological terms [3].

With the population of approximately 65.5 million inhabitants, SEE region makes around $8.9 \%$ of Europe's total population [4]. An average median age of the population in the year 2014 was 39.8 years, which is about $6 \%$ below the average of the European Union (EU28) [5], while the rate of population older than $60 \%$ was $22 \%$. Urban population accounts for $59 \%$ of the total population in the region: Bulgaria having the highest rate of urban population with $75 \%$, while the lowest share has Bosnia and Herzegovina (B\&H) with $50 \%$. The region recorded depopulation between years 2013 and 2014 at a level of $0.14 \%$, which is largely due to the fact that the total number of emigrants from SEE countries was 77,342 [4]. Differences in economic development within the region are significant, since the highest gross domestic product (GDP) per capita of $23,962 \$$ records Slovenia and the lowest GDP of $3877 \$$ has Kosovo, also the Europe's youngest country [6]. Therefore, average GDP per capita of $9922 \$$ is only $28 \%$ of the EU28 average. Great differences can be noticed in geographical characteristics and climate conditions as well. Region consists of several main geographical features, from mountain chains such as the Alps, Dinarides and Carpathians extending through Slovenia, Croatia, $\mathrm{B} \& \mathrm{H}$, Serbia, Montenegro and Kosovo to the Mediterranean and Ionian Sea in Greece and Adriatic Sea in Croatia, Montenegro and Albania. Total area of the region is $765,884 \mathrm{~km}^{2}$, Romania being the largest country by far with $238,391 \mathrm{~km}^{2}$ (or $31 \%$ of the total area), while Slovenia and Montenegro are the smallest, with $20,256 \mathrm{~km}^{2}$ and $13,812 \mathrm{~km}^{2}$, respectively. Average population density is 85.5 people $/ \mathrm{km}^{2}$, which is $23.6 \%$ lower than the EU28 average [6]. Southern part of the region, with a moderate climate and dry summers with a large number of sun hours, distinguishes from northern and eastern part's continental climate, with long and hot summers, but also cold and intensive winters [7].

State of the art of regionally integrated energy systems, and impacts of the integration on countries involved, is described in the following articles. Authors in [8] analyse the advantages of regionally integrated electricity supply system in comparison with power generation system of individual countries in the Western Africa. Results show that integrated system has 38\% lower total electricity production compared to individual systems. The advantages of inter-regional integration of electricity market for the case of East China have been analysed in [9]. Results demonstrate that electricity utilities in the inter-regional electricity market dispose with larger generation capacity, while market can benefit from more optimal usage of resources and capacity. Challenges of greater regional energy co-operation in the South Asia region, one of the fastest growing regions in the world, have been discussed in [10], while social cost-benefit analysis of two electricity interconnector investments in Europe has been conducted in [11]. In [12] authors show how the cross-border electricity transmission has a significant importance when a country or a region has an increased electricity production from intermittent RES. Furthermore, author in [13] describes the case of Nordic countries, the world leaders in electricity production from RES, which achieved successful regional cooperation which should be followed by other countries and regions. Analysis in [14] shows that the penetration level of RES is highly determined by the flexibility of the system.
Finally, in order to reach the goals from [15], storage and balancing synergies have to play an important role in future energy systems.

Evaluation of reliability of Integrated Energy System (IES) has been conducted in [16]. Authors analysed IES as a regional energy system that includes various sub-systems, such as electricity, gas, heating and cooling, and other energy supply systems. Importance of integration of electrical and heating systems, in order to facilitate implementation of RES, is also emphasized in [17]. Authors concluded that cooperation between these two sectors can reduce fuel consumption and energy losses. Novelty in this paper is interplay between transport and industry sectors with energy supply systems (heat and electricity), which increases possibility to integrate even more fluctuating RES and reduce fuel consumption and losses further.

In [18] author provides an overview of the electricity production systems in 10 countries in SEE during 1995-2004 and investigates the potential of integration of electricity markets. Author concludes that an efficient regional energy market would help to meet peak demand in individual countries and significantly increase reliability and stability of electricity supply across the region. However, it emphasizes high level of dependency on hydro and thermal (fossil and nuclear) electricity production. Congestion management methods, as well as infrastructural transmission assets in the region are described in [19]. This paper also stresses importance of establishing regional electricity market in order to allow more cost-effective electricity production. European Union electricity reform is explained in [20], together with its relation to the SEE electricity market. Paper expresses doubts that EU model is completely applicable and good for SEE region. Furthermore, The Energy Community, experiment in a creation of regional energy market between the EU and SEE partners, is described in [21]. Achievements in the process of establishing a stable market framework and regulation conditions within the Energy Community are described in [22]. Here author also emphasizes importance of the SEE regional electricity market formation as a first step towards the integration with the EU market. Within the $2030 \mathrm{Cli}$ mate and Energy Policy Framework, European Commission stated the target of achieving 15\% of existing electricity interconnections for Member States which have not yet accomplished a minimum level of integration in the EU energy market by the year 2030 [23]. Furthermore, importance of cooperation between countries, governments, energy planners and utilities on both financial and policy side in order to achieve economic growth when implementing RES is discussed in [24]. Abovementioned papers present state of the art of energy system integration in SEE, with the focus on policies to further integrate the region in the EU market.

Several papers deal with the planning of low-carbon energy systems with a high share of RES. In [25] author describes approach in creating $100 \%$ renewable energy systems that are technically feasible, sustainable in terms of bioenergy use and economic competitive with fossil fuels. Furthermore, authors in [26] presented a planning method of the $100 \%$ independent Croatian energy system with the special emphasis on RES, energy storage technologies and different regulation strategies. In their work, they reached $78.4 \%$ share of RES and significant $\mathrm{CO}_{2}$ emissions reduction, concluding that in order to achieve $100 \%$ independent or $100 \%$ RES, a detailed planning of all sectors has to be carried out. Similar research has been conducted in [27], where $100 \%$ renewable energy system for the case of Macedonia is presented as possible, but only with a different storage technologies. However, in that scenario usage of biomass is too high taking into account the national potential, so it was concluded that $50 \%$ renewable energy system in the year 2050 is much more realistic. Beside traditional uses of RES, there is a vast potential to exploit new and emerging technologies such as high altitude wind energy [28]. High potential of implementing this type of renewable energy in SEE region has been proved in 
[29]. Potential for biogas production in one county of Croatia using a bottom-up methodology was assessed in [30]. Authors in [31] created three scenarios to reduce $\mathrm{CO}_{2}$ emissions in Western Europe by $96 \%$, with the shares of $40 \%, 60 \%$ and $80 \%$ electricity production from RES. Transition of Mexican electricity system from fossil fuels to RES has been presented in [32]. In order to meet the goals set by the Mexican Congress, authors created three high-RES scenarios and achieved 35\% RES electricity production in the year 2024, including sustainable use of biomass. However, they focus only on the power generation sector and the latter does not include plans for the year 2050. Furthermore, three scenarios for two countries in South East Asia for the year 2050 have been created in [33]. Focus was on transition of electricity sector towards RES in order to reduce $\mathrm{CO}_{2}$ emissions. As a result, they achieved the RES share of $40 \%$ of total electricity production in Indonesia and 39\% in Thailand. Novelty in this paper presents a $100 \%$ renewable energy system that includes integration of power, heat, gas and transport sectors in SEE.

Majority of the papers mentioned above focus solely on the integration of electricity markets in SEE, excluding benefits from the cross-sector inter-regional integration. Exception is [34], where $100 \%$ renewable SEE has been modelled. However, in their work too much emphasize was put on power system, which led to unsustainable use of biomass. Consumption of 1670 PJ of biomass was calculated, while the sustainable potential is equal to only $730 \mathrm{PJ}$ (Bulgaria, Greece and Romania [35], Albania, B\&H, Croatia, Macedonia, Montenegro and Serbia [36], Kosovo [37], Slovenia [38]). Furthermore, excessive investment in pumped hydro storage (PHS) was assumed (increase of $15.6 \mathrm{GW} \mathrm{h}$ ), which will be hard or almost impossible to meet taking into account PHS potential as calculated in [39]. Improvement in the modelling approach in this paper compared to [34] is the sustainability in usage of biomass, which is met by a number of interactions between different sectors of the energy system.

Thus, the novel approach shifts the focus from sectoral to a holistic view when modelling different energy sectors, such as power, heat and gas systems (including mobility), augmented with the regional integration of energy system (geographical integration). This approach leads to the detection of synergies between different sectors and areas which would remain undetected by solely focusing on partial solutions, such as smart grids, which allows more intermittent energy sources to be integrated in the energy system. Furthermore, it makes transition to zero-carbon energy system feasible considering only locally sustainable potential of the biomass, as opposed to studies where biomass import over the system boundaries is allowed.

Another novelty is that the integration of $100 \%$ RES energy system is planned for regions that are parts of the same synchronous electricity network and interconnected gas grids, but having different political systems. Five of the analysed countries are EU member states, four candidate countries and two potential candidates. The majority of them are members of European Network of Transmission System Operators for Electricity ENTSO-E and the European Network of Transmission System Operators for Gas ENTSO-G, while several countries act as observers in these associations. Planning of $100 \%$ RES system in this way can show another benefit for mutual cooperation and bonding on energy system planning.

Scenarios are developed for the reference year, which was set in this paper to 2012, and for the year 2050. The modelling tool used in this paper is EnergyPLAN. In the year 2050 the whole region is considered to be $100 \%$ renewable. In this paper the SEE region consists of eleven countries: Albania, Bosnia and Herzegovina, Bulgaria, Croatia, Greece, Kosovo, Macedonia, Montenegro, Romania, Slovenia and Serbia.

The goal of this paper is to model a zero carbon energy system in a technically feasible way (critical excess in electricity production needs to be less than $5 \%$, while the system is modelled as a closed one, setting transmission capacity with the neighbouring countries to zero), using realistic measures and penetrations of specific technologies, not exceeding their technical potentials. Furthermore, the system needs to be robust and thus, it should not depend heavily on one technology; it should rather contain mix of different technologies. Finally, the total socio-economic cost should be as low as possible, keeping in mind that the system should be technically possible and realistic to achieve. Further novelty in this paper is that the $100 \%$ renewable SEE will be modelled by consuming biomass in a sustainable way, i.e. within the limits of biomass potential in the region.

Section 2 of the paper is dedicated to the description of the methodology and EnergyPLAN model, after which the case study and scenarios have been described in Section 3. Results of the case study are presented in Section 4, while the discussion part focuses on the comparison of the results with the other state of the art work. Finally, sensitivity analysis is carried out for the case of extremely dry year, in order to assess the consequences of reduced hydro power plants production and possible water scarcity due to climate change, followed by the main conclusions.

\section{Methodology}

In this paper, the concept of smart energy systems is adopted. Contrary to the concept of smart grids, where emphasis is put only on one part of the energy system, the power sector, the concept of smart energy system detects and utilizes synergies between different sectors of energy system, i.e. power system, heating sector and gas grid [40]. Moreover, in order to adopt smart energy system concept correctly, biomass has to be used in a sustainable way and thus, only certain part of forest residue should be used as a primary energy source. A model, specially developed for modelling of smart energy systems is EnergyPLAN, developed at Aalborg University [40].

Today, many different models for energy planning exist. A great review of energy planning tools is given in [41]. According to it, out of many tools only seven of them incorporate electricity, heat and transport sectors, while only four of them have already simulated $100 \%$ renewable energy system, i.e. EnergyPLAN, MesapPlaNet, INFORSE and LEAP. In this study, hourly analysis is preferred as it allows detecting instabilities in the power grid, as well as the nature of critical excess in electricity production, its frequency and the magnitude. Out of mentioned four modelling tools, only EnergyPLAN and MesapPlaNet have the possibility of hourly time steps simulation. Furthermore, MesapPlaNet has a very small number of users [41] and it was used only in Greenpeace studies for simulation of $100 \%$ renewable energy system in the year 2007 [42], 2008 [43], 2010 [44] and 2012 [45]. On the other hand, EnergyPLAN is already a well-established tool for modelling $100 \%$ renewable energy systems. It was used for modelling of $100 \%$ RES in the following countries: Portugal [46], Macedonia [27], the Netherlands [47], Latvia [48], Ireland [49], Croatia [26] and Denmark [50]. Overview of several $100 \%$ renewable energy systems modelled was given in [51]. Furthermore, the model was used for the assessment of the $100 \%$ renewable EU28 [52]. As it satisfies all the needs for this study, EnergyPLAN was chosen to be a modelling tool for calculating 100\% renewable SEE in the year 2050 .

The EnergyPLAN model is a detailed input/output model. Inputs that need to be set are energy demands in general, renewable energy sources, energy conversion units such as electrolysers, energy plant capacities, costs and a regulation strategy. Outputs are energy balances and resulting annual productions, fuel consumption, import/export and total costs including income from the export of electricity [53].

Concerning the total system cost as an output of the model, it can present a socio-economic costs or business economic costs. 
The socio-economic costs were used as an output in this paper, which encompasses levelized investment costs of the energy plants over their lifetimes, fuel costs, fixed and variable operating and maintenance costs, as well as $\mathrm{CO}_{2}$ taxes as environmental externality. It is worth mentioning here that taxes in general are not included in the calculation of socio-economic costs as they are considered to be only internal redistributions within the society. Furthermore, costs of implementing energy efficiency measures or advising costs of consulting companies during the preparation phase of the projects are not incorporated in the socio-economic cost in this paper. However, although implementing energy efficiency measures can impose high upfront costs, they will be offset by the savings in energy spending. Hence, in the long term these measures will actually lower the total socio-economic costs even more than calculated here.

Detection of health consequences and job creation opportunities are externalities that remained outside of the scope of this paper when determining total socio-economic costs, although inclusion of these figures would gain more beneficial results for renewables dominated energy system. In support of the latter statement, authors in [54] calculated that the transition towards renewable energy system in China in the year 2050 would create 4.12 million jobs. Furthermore, including currently externalized health costs of the Danish heat and power sectors would decrease total health costs by $18 \%$ [55]. It has been showed on the case of Taiwan in [56] that the net benefits of avoided premature deaths, averted morbidity, savings in social costs and years of life lost are equal to 118,279 million USD during the period 2010-2030.

The model simulates energy system behaviour during one year in hourly resolution (8784 steps) and thus, it is a suitable tool for analysis of intermittent RES, as well as the hourly, daily and seasonal fluctuations in energy demand.

The model can be applied from the municipality levels to the European level. The model describes the interaction between the combined heat and power (CHP) plants and the RES especially well, in the same time allowing the interplay between the heating and power systems. By various means interplay between gas grids and the heating and electricity systems is well modelled, too [53].

On the other side, constraints of the model are its aggregated approach to power plants' modelling, where all the thermal power plants are represented by the total capacity and fuel distribution percentages between coal, natural gas, oil and biomass. Similarly, heat storages and district heating plants are modelled only in three groups, which can possibly cause misinterpretation of the modelled system due to the geographical constraints that can occur in the real system. Furthermore, the system is treated as a single point without internal congestion management modelling. As a consequence, it cannot be clear from it whether there are disbalances and congestion in transmission and distribution networks between different regions and/or countries. Also, it is important to emphasize that the model does not distinguish between different types of biomass. An important comparison between optimization model such as TIMES and simulation model such as EnergyPLAN has been presented in [57].

The complete system interactions of the model can be seen in Fig. 1.

Technical simulation will be used in the model, which seeks to find the solution with the minimum consumption of fuels, i.e. with minimum emissions of $\mathrm{CO}_{2}$.

\section{Case study: Zero carbon SEE in the year 2050}

\subsection{Reference energy system (2012)}

Reference energy system was built for every country independently, validated against the International Energy Agency's data [58] and then joined together in the one energy system.

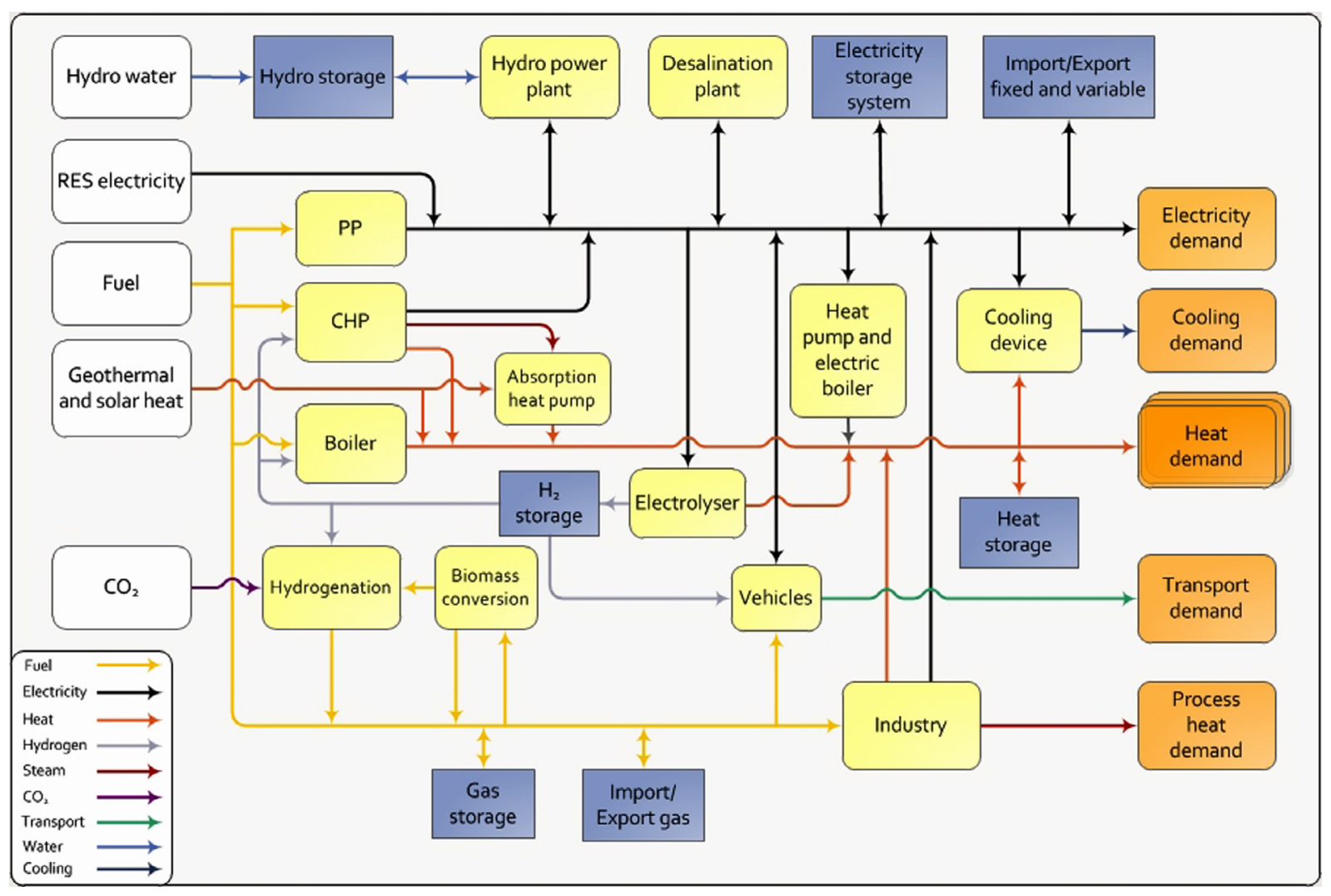

Fig. 1. The EnergyPLAN model in version 11.4 [40]. 
Table 1

Installed generation capacity in the SEE region.

\begin{tabular}{|c|c|c|c|c|c|c|c|c|c|}
\hline Country & Year & Ref. & Hydro [MW] & Thermal [MW] & Nuclear [MW] & Biomass [MW] & Wind [MW] & PV [MW] & Other RES [MW] \\
\hline Albania & 2012 & [62] & 1450 & 0 & 0 & 0 & 0 & 0 & 0 \\
\hline $\mathrm{B} \& \mathrm{H}$ & 2012 & [63] & 2034 & 1590 & 0 & 0 & 0 & $2.4[64]$ & 0 \\
\hline Bulgaria & 2012 & [65] & 2864 & 6613 & 2000 & $20[66]$ & 684 & 908 & 0 \\
\hline Croatia & 2012 & [67] & 2136 & 1681 & 0 & 13.8 & 180 & 4 & 0 \\
\hline Greece & 2012 & [65] & 2817 & 9741 & 0 & 39 & 1865 & 1039 & 0 \\
\hline Macedonia & 2012 & [68] & 578 & 800 & 0 & 0 & 0 & 1.6 & 0 \\
\hline Montenegro & 2012 & [69] & 660 & 208 & 0 & 0 & 0 & 0 & 0 \\
\hline Romania & 2012 & [70] & 6195 & $9460[71]$ & 1300 & 89 & 1905 & 51 & 0 \\
\hline Serbia & 2012 & [72] & 2910 & 4642 & 0 & 0 & 0 & 0 & 0 \\
\hline Slovenia & 2012 & [73] & 1254 & 1495 & 696 & 41 & 2 & 240 & 0 \\
\hline Kosovo & 2012 & [74] & 43 & 885 & 0 & 0 & 0 & 0 & 0 \\
\hline Total & 2012 & & 22,941 & 37,115 & 3996 & 202.8 & 4636 & 2246 & 0 \\
\hline
\end{tabular}

Electricity data was obtained from ENTSO-E [59], except for Albania and Kosovo, countries for which the electricity data is not available on ENTSO-E. Demand for these countries was calculated by obtaining monthly demand values from [50,51] and scaling it on hourly resolution using the average of other SEE countries' profiles. As these two countries represent only $7 \%$ of the total population in SEE, this assumption will not cause a significant impact on overall results. Heat demand was calculated using the degreehour method, while the hourly temperatures were obtained from [60]. Solar radiation curves, river hydro and dammed hydro distribution profiles were used for the year 2008 [40] and adapted to the yearly values of hydroelectric power plants generation obtained from the International Energy Agency (IEA) [58].

Wind speed data was obtained from EnergyPLAN database of measured data for the year 2008 [25] and adapted to the capacity factor in 2050 as calculated in [61]. As showed in [45,46], average yearly wind speed is usually between the $10 \%$ range from the mean and seldom in the range of $20 \%$ from the mean for the specific location. Furthermore, as the system modelled is not excessively dependent on wind (less than one third of the electricity generation), it is assumed that the system is robust enough to deal with these small fluctuations between different years. Moreover, as the modelled geographic area is large, the differences in annual wind speeds for a specific location flattens out when many wind farm locations are considered.

Economic data, which includes investment costs, energy plant lifetimes, fixed and variable operating and maintenance costs were taken from the official website of the model developers [40]. The cost database is constantly being updated and can be freely accessed. Discount rate was set to $3 \%$ and $\mathrm{CO}_{2}$ emissions cost in the year 2050 is set to $46 € /$ ton. However, the latter number does not have any influence upon the result as the system in 2050 is already the zero-carbon one.

The majority of capacity in SEE is linked with thermal and hydroelectric power plants, i.e. 37.8 and $23.1 \mathrm{GW}$. Out of total capacity of hydroelectric power plants, $83.6 \%$ are dammed power plants (including cascade power plants), while $16.4 \%$ are run-ofriver hydro power plants. Nuclear power plants are installed in Romania, Bulgaria and Slovenia with the total capacity of nearly $4 \mathrm{GW}$. Wind energy is a dominant RES technology with installed capacity of $4.6 \mathrm{GW}$ in 2012, followed by photovoltaics (PVs) with installed capacity of $2.2 \mathrm{GW}$.

A detailed list of power plants for each country for the year 2012 can be seen in Table 1.

The $\mathrm{CO}_{2}$ contents of $74 \mathrm{~kg} / \mathrm{GJ}$ for fuel oil, diesel and petrol, $56.7 \mathrm{~kg} / \mathrm{GJ}$ for natural gas and $101.2 \mathrm{~kg} / \mathrm{GJ}$ for coal have been used in the analyses [40].

\subsection{Zero carbon energy system in 2050}

Building a $100 \%$ renewable energy system, while consuming biomass in a sustainable way consists of several steps.
Firstly, power and district heating sectors need to be integrated in order to allow more than $20 \%$ of intermittent electricity production (wind and PVs). The integration of these two sectors needs to be achieved by advanced CHPs and heat pumps coupled with thermal energy storage, in order to increase efficiency of the system and reduce the overall fuel consumption. Secondly, electrification of majority of light vehicles needs to be introduced. Vehicle-togrid (V2G) technology needs to be implemented in order to help balancing out the electrical grid. Moreover, where possible, pumped storage hydroelectric power plants need to be installed to further improve integration of intermittent energy sources. A next step is penetration of wind power and PVs on a large scale, especially as for the latter technology a significant drop in investment costs is anticipated. Furthermore, other RES such as waste incineration power plants, small hydro power plants and concentrated solar power with thermal storage (CSP) are introduced. In the heating sector, it is especially important to introduce geothermal energy on a large scale.

In the transportation sector, medium and heavyweight vehicles which cannot be electrified by current battery technology need to be fuelled by either biofuels or electrofuels. As technologies for electrofuels are still not in the commercial phase, majority of transportation means is assumed to be driven by biofuels or synthetic fuels produced from biomass.

In individual heating sector, parts of houses and buildings which cannot be connected to district heating grid need to be heated by heat pumps or solar thermal energy. If none of these technologies are suitable, individual biomass boiler technology will still be used.

Overview of measures on the demand side of the model and references of each implemented measure can be seen in Table 2. On the other hand, measures implemented on the supply side of the system are presented in the Table 3.

\section{Results}

Analyses were made in EnergyPLAN looking at SEE as a closed system and thus, transmission capacity to neighbouring countries was set to zero. Thus, all the generated excess electricity was considered to be a critical one and abbreviation CEEP is used to denote it (Critical Excess in Electricity Production).

\subsection{Reference scenario validation}

In order to validate the model, reference scenario made for the year 2012 was validated against the data obtained from the IEA [58].

As it can be seen from Table 4, the reference model developed for the year 2012 matches well with the data obtained from the IEA. The total $\mathrm{CO}_{2}$ emissions differ 3.5\%, while total primary energy 
Table 2

Measures on the demand side of the system.

\begin{tabular}{|c|c|c|}
\hline Measure & Ref. & Discussion \\
\hline Efficiency increase in individual houses by $50 \%$ & [75] & $\begin{array}{l}\text { In Energy Efficiency scenario of Energy Roadmap } 2050 \text { a staggering } 72 \% \text { of } \\
\text { increased efficiency is assumed; it is assumed here that it is exaggerated, as it } \\
\text { was argued in [52] and thus, } 50 \% \text { of increased efficiency is assumed }\end{array}$ \\
\hline Energy efficiency increase of $50 \%$ in households supplied by district heating & [75] & $\begin{array}{l}\text { In Energy Efficiency scenario of Energy Roadmap } 2050 \text { a staggering } 72 \% \text { of } \\
\text { increased efficiency is assumed; it is assumed here that it is exaggerated, as it } \\
\text { was argued in [52] and thus, } 50 \% \text { of increased efficiency is assumed }\end{array}$ \\
\hline $\begin{array}{l}\text { Replacement of } 52.5 \% \text { of individual heating houses with small scale district } \\
\text { heating ( } 1.5 \% \text { per year) }\end{array}$ & {$[52]$} & $\begin{array}{l}\text { In Heat Roadmap Europe } 2050 \text { an increase in DH from } 12 \% \text { to } 50 \% \text { is assumed } \\
\text { for the same period. As the penetration in the base year for SEE is already } \\
\text { higher than } 20 \% \text {, it is assumed that it is viable to achieve the penetration of DH } \\
\text { of } 51.5 \% \text {. Furthermore, in [76] it was shown that small scale biomass driven } \\
\text { cogeneration system is economic feasible investment if pit thermal energy } \\
\text { storage is used for peak purposes instead of boilers }\end{array}$ \\
\hline $\begin{array}{l}50 \% \text { of final heating demand of houses not connected to the DH is met by heat } \\
\text { pumps, } 20 \% \text { by solar thermal and } 30 \% \text { by biomass boilers }\end{array}$ & [77] & $\begin{array}{l}\text { Measures adopted from the references with slightly higher share of biomass } \\
\text { adopted as it is expected due to the much larger penetration of biomass } \\
\text { nowadays that a slightly larger share will it have in the year } 2050\end{array}$ \\
\hline $\begin{array}{l}\text { In industry, increased efficiency of } 2 \% \text { per year is leveled out with the same } \\
\text { increase in industrial activity, which is set to } 2 \% \text { per year in average for the } \\
\text { whole region }\end{array}$ & [52] & $\begin{array}{l}\text { Measure adopted from the reference without any modifications. } \\
\text { There are many measures for increase of energy efficiency in industry, e.g. [78] } \\
\text { showed the possibility of achieving energy savings of } 8.2 \% \text { in a crude } \\
\text { distillation unit using the process integration techniques }\end{array}$ \\
\hline $20 \%$ of demand in industry is met by industrial CHPs & [52] & Measure adopted from the reference without any modifications \\
\hline $15 \%$ of demand is met by solar thermal energy with storages & [79] & $\begin{array}{l}\text { According to the reference share of solar thermal energy in industry could } \\
\text { reach up to } 33 \% \text {. More conservative approach was assumed in this paper and a } \\
\text { share of } 15 \% \text { has been adopted }\end{array}$ \\
\hline $45 \%$ of energy demand of fossil fuels in industry is replaced with electricity & [80] & $\begin{array}{l}\text { New efficient induction furnaces are coming to the market. As shown in the } \\
\text { reference, induction plant can replace conventional gas or oil-fired furnace, } \\
\text { significantly reducing the consumption of fuels and as a consequence lower the } \\
\text { greenhouse gas emissions (GHG). Thus, it is assumed that a large portion of } \\
\text { energy intensive industries will shift to induction furnaces }\end{array}$ \\
\hline Remaining coal and oil consumption is replaced by biomass & [77] & Measure adopted from the reference without any alterations \\
\hline $\begin{array}{l}\text { In transport sector } 20 \% \text { energy savings needs to be achieved by improved } \\
\text { public transportation system and replacement of one part of individual } \\
\text { vehicles with public transportation (mainly electrified trains) }\end{array}$ & [77] & Measure adopted from the reference without any alterations \\
\hline Total electrification of railway system & [77] & Measure adopted from the reference without any alterations \\
\hline $\begin{array}{l}100 \% \text { of light transport vehicles and } 35 \% \text { of medium transport vehicles is } \\
\text { replaced by electrical vehicles; out of these } 85 \% \text { will be using smart charge } \\
\text { system, while } 15 \% \text { dumb charge system }\end{array}$ & [77] & Measure adopted from the reference without any alterations \\
\hline $\begin{array}{l}\text { Remaining part of transport sector demand is met by synthetic fuels produced } \\
\text { mainly by chemical synthesis from biogas (hydrogenation of biomass); } 25 \% \\
\text { of fuel demand is met by } \mathrm{CO}_{2} \text { hydrogenation using electricity as energy } \\
\text { input }\end{array}$ & [81] & $\begin{array}{l}\text { As using biomass (e.g. rapeseed) for biofuels has been criticized due to the } \\
\text { competition with the food supply chain, land use impacts [82], sustainability } \\
\text { problem and impacts on land resources [83], a hydrogenation of biomass was } \\
\text { introduced as it uses less biomass from biofuels and better integrates } \\
\text { intermittent RES in the system [81] }\end{array}$ \\
\hline
\end{tabular}

supply differs for $1.4 \%$. It can be also seen that resulting fuel emissions are slightly different in the reference model compared to the IEA data, as the difference in $\mathrm{CO}_{2}$ emissions is slightly greater than the primary energy supply (PES) difference.

\subsection{Comparison of energy systems in years 2012 and 2050}

In Fig. 2 the total primary energy supply for the year 2012 and 2050 can be seen. In 2050, the whole energy supply is renewable and the total biomass consumption is sustainable, i.e. its consumption is equal to 201.65 TWh. Biomass potential in all countries for the year 2012 can be seen in Table 5 .

Thus, modelled biomass consumption is within the biomass potential. According to the reference [98], 71\% of the total potential of sustainable biomass in Western Balkans (Albania, B\&H, Croatia, Macedonia, Kosovo, Montenegro and Serbia is attributed to woody biomass (i.e. residuals from wood industry, logging residuals, residuals from pruning different fruit trees, olive trees or vineyards and firewood) and $29 \%$ to agricultural biomass (i.e. food-based and nonfoodbased portions of crops such as wheat, barley or corn residuals). Therefore, the same share can be used for the SEE region in this case.

In Fig. 3, detailed renewable energy generation by sources can be observed.
The largest share in electricity production have wind and PVs with $28.9 \%$ and $22.5 \%$, followed by dammed hydro, CSP, biomass driven plants (mainly CHPs), geothermal and river hydro. It is important to note that none of technologies exceed $30 \%$ of generation share on yearly basis, which shows that the system is robust and is able to cope with fluctuations in generation of specific technologies between the different years. Moreover, large geographic scale of integrated energy system of SEE evens out fluctuations of certain generation technologies at a local level.

It is interesting to compare generation of electricity on hourly resolution during the two days in summer and winter, which is presented in Fig. 4:

It can be seen that PVs are dominating the generation mix during the summer. Beneficial feature of the power system during the summer is that PV production corresponds to the peak consumption. In the summer day during the evening and night, the majority of generation comes from dammed hydro plants. Furthermore, it should be noted that the pump hydro plants are working during the night with the maximum capacity in the turbine regime, which adds $2 \mathrm{GW}$ of power generation capacity, helping to meet the overall electricity demand as the night in the mid-July being presented had very low wind production.

During the winter, generation of PVs is on a much lower scale. Dammed hydro production had a large share of generation during 
Table 3

Measures on the supply side of the energy system.

\begin{tabular}{|c|c|c|}
\hline Measure & Ref. & Discussion \\
\hline Total capacity of wind set to $50 \mathrm{GW}$ & {$[61,84]$} & $\begin{array}{l}\text { According to the references, the total economic viable wind potential is } \\
137 \mathrm{GW} \text {. However, more conservative approach has been adopted. } \\
\text { (Greece, Romania and Bulgaria [84], other SEE countries from [61]) }\end{array}$ \\
\hline Total capacity of PVs set to $65 \mathrm{GW}$ & [61] & $\begin{array}{l}\text { According to the reference, up to } 50 \% \text { of final electricity demand could come } \\
\text { from PVs in this region }\end{array}$ \\
\hline Total capacity of CSP set to $11 \mathrm{GW}$ & [85] & $\begin{array}{l}\text { According to the reference Spain installed } 1.3 \mathrm{GW} \text { of CSP from } 2006-2012 \text {. } \\
\text { Thus, } 11 \mathrm{GW} \text { of CSP in the SEE till the year } 2050 \text { was assumed as a viable } \\
\text { estimate. (2020-2030 } 2.5 \mathrm{GW}, 2030-20403.5 \mathrm{GW} \text { and period } 2040-2050 \\
5 \mathrm{GW} \text { of installed capacity) }\end{array}$ \\
\hline Increase in dammed hydro power capacity for $25 \%$, to $23.5 \mathrm{GW}$ & [86] & $\begin{array}{l}\text { According to the reference, technical and economic feasible potential in this } \\
\text { region is still huge and hydropower could be increased by more than two } \\
\text { times. However, due to complicated procedure when building dammed } \\
\text { hydro much more conservative approach has been adopted }\end{array}$ \\
\hline Introduction of $1.5 \mathrm{GW}_{\mathrm{e}}$ of large scale heat pumps & [87-89] & $\begin{array}{l}\text { As it was shown in the references, large scale heat pumps are beneficial } \\
\text { technology (to solve intermittency and efficiency problems [87], beneficial } \\
\text { in cooperation with CHP systems [88] and beneficial in implementing high } \\
\text { share of RES [89]) for integration of intermittent RES and thus, this } \\
\text { technology has been introduced }\end{array}$ \\
\hline $\begin{array}{l}13.3 \% \text { of heat in } \mathrm{DH} \text { system is met by solar thermal with a } 75 \mathrm{GW} \text { h of } \\
\text { seasonal thermal energy storage }\end{array}$ & [90] & $\begin{array}{l}\text { According to the reference, in municipality of Sønderborg in Denmark a } 20 \% \\
\text { of DH demand is projected to be supplied by solar thermal. Due to the much } \\
\text { larger systems and higher winter peaks, a smaller share of solar thermal has } \\
\text { been assumed to stay on the safe side }\end{array}$ \\
\hline All newly introduced district heating goes to the small scale networks & [76] & $\begin{array}{l}\text { It was shown in the reference that small scale DH networks are economic } \\
\text { feasible in current support system, as well in Feed-in premium system }\end{array}$ \\
\hline Installation of $230 \mathrm{GW} \mathrm{h}$ of seasonal storage in $\mathrm{DH}$ network & {$[91,92]$} & $\begin{array}{l}\text { In Zagreb, a seasonal storage of } 750 \mathrm{MW} \text { h has been built already [91]. } \\
\text { However, due to the large return temperature losses are higher than usual } \\
\text { and the real capacity of this storage in optimal regime is } 1.5 \mathrm{GW} \text { h. In Ref. } \\
\text { [92] it was shown that in Denmark already today a three times larger } \\
\text { storages exist. Thus, it is assumed that each country will build four storages } \\
\text { with equivalent size of the storage built in Marstal, Denmark with the } \\
\text { capacity of } 5 \mathrm{GW} \mathrm{h}\end{array}$ \\
\hline $960 \mathrm{MWe}$ and $2.38 \mathrm{GW}$ h of waste incineration power plants & {$[52,93]$} & $\begin{array}{l}\text { Calculated from Heat Roadmap Europe and scaled due to the population } \\
\text { ratio of SEE and EU } 28 \text { [52]. It is assumed that similar amount of waste is } \\
\text { produced per person. However, to be on the safe side the total potential has } \\
\text { been reduced by } 20 \% \text {. Technical data for waste incineration plant was } \\
\text { obtained from Energinet's report [93] }\end{array}$ \\
\hline 1250 MWe of geothermal PP & {$[94-96]$} & $\begin{array}{l}\text { Technical potential (Croatia and Greece [94], Bulgaria and Romania [96], } \\
\text { Albania, B\&H, Kosovo, Macedonia, Montenegro, Serbia and Slovenia [95]) } \\
\text { adopted without any alterations }\end{array}$ \\
\hline $\begin{array}{l}\text { Adding } 7.5 \mathrm{GW} \text { of geothermal heating energy (in } 205040 \% \text { of heat in } \\
\text { DH is produced by geothermal energy sources) }\end{array}$ & [94-96] & $\begin{array}{l}\text { Technical potential (Croatia and Greece [94], Bulgaria and Romania [96], } \\
\text { Albania, B\&H, Kosovo, Macedonia, Montenegro, Serbia and Slovenia [95]) } \\
\text { adopted without any alterations }\end{array}$ \\
\hline Increase in river hydro and small hydropower plants to $6.8 \mathrm{GW}$ & {$[86,97]$} & $\begin{array}{l}\text { According to [86], SEE utilizes only } 41 \% \text { of economic hydro potential. } \\
\text { Furthermore, [97] estimates much higher potential for each individual } \\
\text { country. However, conservative approach has been adapted to be on the } \\
\text { safe side }\end{array}$ \\
\hline Increase in CHP capacity to $8 \mathrm{GW}$ & {$[52]$} & Adopted according to the reference. \\
\hline $\begin{array}{l}\text { Reduction in thermal power plants capacity to } 24.7 \mathrm{GW} \text { and replacing } \\
\text { its fuel with biomass }\end{array}$ & {$[50]$} & $\begin{array}{l}\text { Adopted according to the reference. The capacity of thermal power plants, } \\
\text { as stated in Table } 1 \text {, is assumed to be gradually reduced towards } 24.7 \mathrm{GW} \text {, } \\
\text { decommissioning the old thermal power plants upon the end of their } \\
\text { lifetimes }\end{array}$ \\
\hline Decommission of all nuclear power plants & & $\begin{array}{l}\text { Due to inflexible operation, high capital costs and already long operation } \\
\text { time it is also not envisaged to have new installations after } 2025\end{array}$ \\
\hline $\begin{array}{l}\text { Introduction of } 11 \text { power plants similar to Avča (total new storage } \\
1067 \mathrm{GW} \text { h (obtained from [39], pumping capacity } 1980 \mathrm{MW} \text { and } \\
\text { turbine capacity } 2035 \mathrm{MW} \text { ) }\end{array}$ & [39] & $\begin{array}{l}\text { Storage within } 5 \mathrm{~km} \text { distance from the lower lake has been taken from the } \\
\text { reference as a viable potential }\end{array}$ \\
\hline
\end{tabular}

Table 4

Validation of reference model.

\begin{tabular}{lrcl}
\hline & $\begin{array}{l}\text { IEA SEE } \\
(\text { TWh })\end{array}$ & $\begin{array}{l}\text { EnergyPLAN SEE } \\
(\text { TWh })\end{array}$ & $\begin{array}{l}\text { Difference IEA - } \\
\text { EnergyPLAN }(\%)\end{array}$ \\
\hline Coal & 466.4 & 468.3 & -0.40 \\
Oil & 438.3 & 437.8 & 0.12 \\
Ngas & 256.5 & 256.9 & -0.15 \\
Nuclear & 99.6 & 99.5 & 0.15 \\
Hydro & 49.1 & 49.7 & -1.26 \\
Biomass & 113.2 & 113.8 & -0.55 \\
Other & 23.0 & 0.0 & \\
CO & $\mathbf{3 2 0 . 7}$ & $\mathbf{3 3 2 . 0}$ & $-\mathbf{3 . 5 2}$ \\
$\quad$ (Mt) & & & $\mathbf{1 . 3 9}$ \\
PES & $\mathbf{1 4 4 6 . 2}$ & $\mathbf{1 4 2 6 . 0}$ &
\end{tabular}

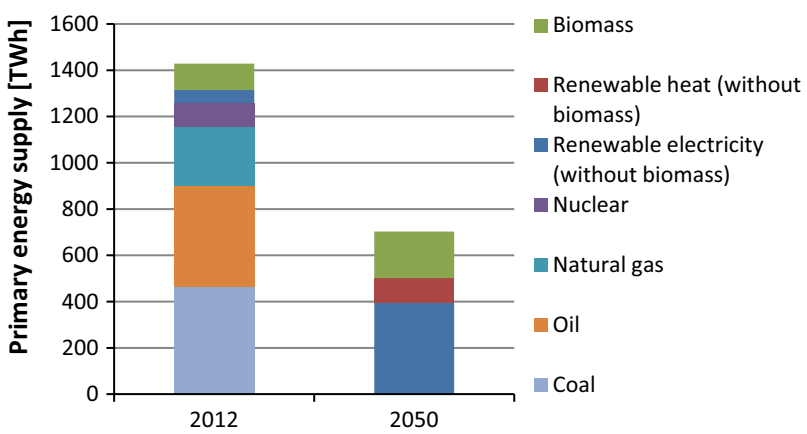

Fig. 2. Primary energy supply in the year 2012 and 2050. 
Table 5

Biomass potential of countries located in SEE (Bulgaria, Greece and Romania [35], Albania, B\&H, Croatia, Macedonia, Montenegro and Serbia [36], Kosovo [37] and Slovenia [38]).

\begin{tabular}{lcr}
\hline Biomass potential & PJ & TWh \\
\hline Slovenia & 19.6 & 5.4 \\
Greece & 27.10 & 7.5 \\
Croatia & 56.14 & 15.6 \\
Montenegro & 12.03 & 3.3 \\
Serbia & 136.8 & 38.0 \\
B\&H & 56.41 & 15.7 \\
Albania & 29.79 & 8.3 \\
Kosovo & 4.85 & 1.3 \\
Macedonia & 21.61 & 6.0 \\
Bulgaria & 44.36 & 12.3 \\
Romania & 318.03 & 88.3 \\
Total & 726.74 & 201.9 \\
\hline
\end{tabular}

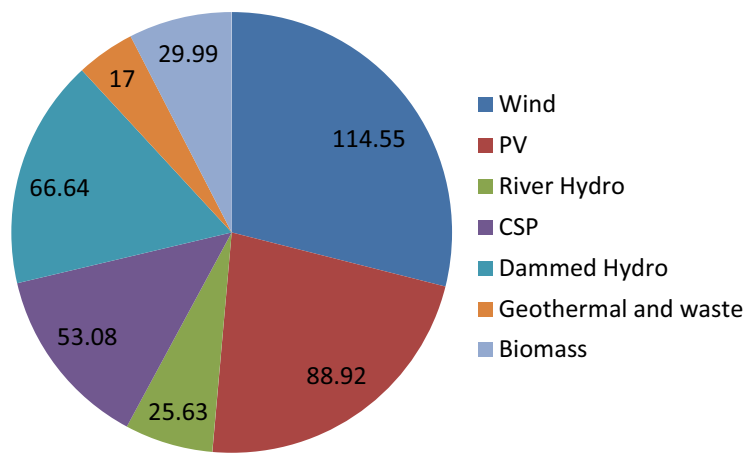

Fig. 3. Mix of renewable electricity generation in the year 2050 [TWh].

the evening. However, during the night in winter period, dammed hydro production is lowered down due to the higher generation of wind energy. Moreover, the peak demand and the trough demand do not differ as much as during the summer period.

Finally, evaluation of the energy system from the technical point of view in the year 2050, compared to the current system
(2012), can be assessed by taking a closer look at the data presented in Table 6.

It can be seen from Table 6 that the primary energy supply has decreased significantly (50.7\%), while the $\mathrm{CO}_{2}$ emissions reduced to zero in the year 2050. Critical excess in electricity production is equal to 15.64 TWh or $4.4 \%$ of the total electricity production. However, it is important to note here once again that the system of the SEE was modelled as a closed system, without transmission to the neighbouring countries. By using different strategies, such as gasification and production of synthetic fuels when there is an excess in electricity production, CEEP can easily be reduced for $50 \%$. Nevertheless, further decrease in CEEP can be achieved by introducing the transmission capacity to the neighbouring countries [99]. It is worth mentioning here that besides having $100 \%$ renewable energy system in the year 2050, the total annual socio-economic cost is almost 20 billion EUR lower in the year 2050 compared to the reference year. Thus, although higher costs can occur during the initial phases of transformation to the $100 \%$ renewable energy system due to the high upfront costs, the final energy system can be cheaper compared to the one heavily dependent on fossil fuels.

\section{Discussion}

In [76] authors presented biomass driven trigeneration system coupled with pit thermal energy storage on a case study for one district in Croatia. They have showed that building small scale cogeneration units can be beneficial in economic terms. This approach has been also confirmed in this model, as small scale CHP systems increase fuel efficiency of the system and thus, decrease the total biomass consumption. Furthermore, along with the heat pumps and thermal storage, CHP plants are used to integrate heating and power sectors which leads to further increase in efficiency.

In [100] the influence of energy policy on energy demand was assessed on a case study of Croatia. By inclusion of policy measures in different scenarios, achieved energy efficiency improvements equalled to $23 \%$ in industry, $25 \%$ in households and $27 \%$ in trans-
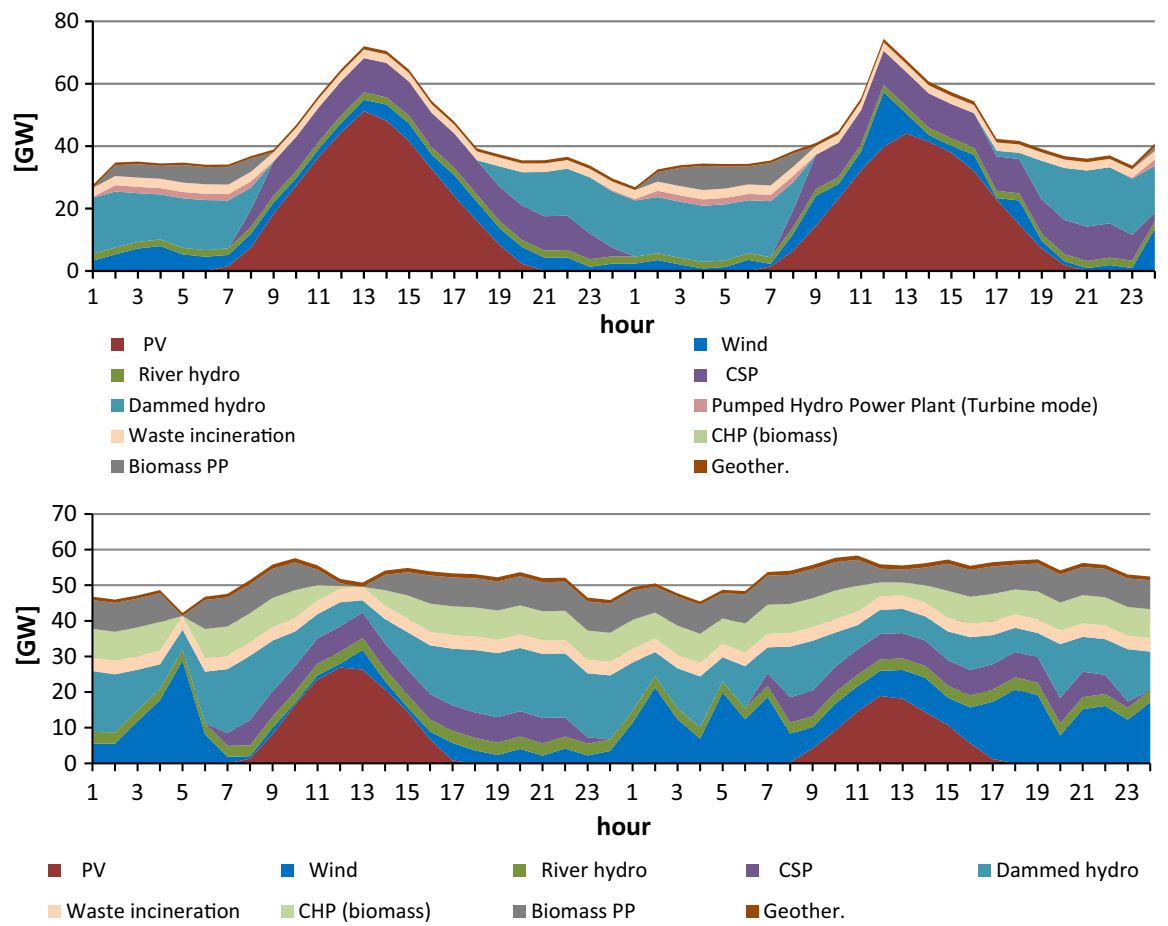

Fig. 4. Electricity generation mix during two days in mid-July (up) and in the beginning of January. 
Table 6

Comparison of different parameters of energy systems in the year 2012 and 2050.

\begin{tabular}{lll}
\hline & 2012 & 2050 \\
\hline PES [TWh] & 1426 & 702.86 \\
$\mathrm{CO}_{2}$ emissions [Mt] & 332 & 0 \\
$\mathrm{CEEP}$ [TWh] & 0 & 15.64 \\
Total annual socio-economic cost [MEUR] & 63,903 & 44,415 \\
\hline
\end{tabular}

portation sector. Total savings in PES after the measures were adopted equalled 22\%. Moreover, overall biomass consumption for the case of Croatia is not completely clear so the sustainability in usage of biomass remained unclear.

In this paper, measures proposed in several different papers for the case of Denmark, Energy roadmap 2050 and Heat roadmap 2050 were adapted or directly adopted. Moreover, certain energy efficiency goals proposed in Energy roadmap 2050 were argued as exaggerated and measures from other references were adopted. By using referenced energy efficiency measures in this paper, a total primary energy savings equalled to a significant $50.7 \%$. Although the expenses for increased energy efficiency measures are greater in the beginning, the total socio-economic costs for the year 2050 will be lower.

In [61], the biomass consumption was unsustainable, as already shown in the introduction, and the excessive investment in pumped hydro storage was assumed. Furthermore, primary energy supply is equal to 943.6 TWh and the largest share in electricity consumption has wind (34\%), followed by PV (20\%), river hydro (14.4\%) and pumped hydro plant (14\%) generation. Yearly modelled biomass consumption amounts to $1690 \mathrm{PJ}$. Reported $\mathrm{CO}_{2}$ emissions in 2050 are equal to zero while primary energy supply is 33.8\% lower compared to the reference year (2008).

In this paper total primary energy savings are equal to $50.7 \%$, $726 \mathrm{PJ}$ of biomass is consumed annually and pumped hydro storage is increased only till its technical limit as referenced in Table 3. Thus, PES in this paper is $34 \%$ lower and the biomass consumption is $57 \%$ lower than in [61]. This proves that greater energy efficiency of the system can be achieved by the better integration of the whole energy system, compared to the solely focusing on the power sector. Furthermore, biomass consumption in integrated energy system can be reduced to the sustainable level.

It is of crucial importance to clarify that the statement "the better integration of the whole energy system" refers to the integration of power, heating and gas sectors (including transportation), complemented with the regional integration (geographical integration) of the energy systems. This integration leads to the better technical system in terms of managing the intermittent energy sources and robustness of the modelled system in general, as well as to cheaper energy system considering the socio-economic costs. On the other hand, taking only power sector into consideration, in so called smart grids, leads to the partial solution that cannot detect possible synergies between different energy sectors. As a consequence, the latter approach will lead to either more expensive system in terms of socio-economic costs or to less viable energy system from technical point of view, represented in the ability to integrate intermittent renewable energy sources.

The possibility of carbon capture and storage (CCS), coupled with coal fired thermal power plant in the SEE has been assessed in [101]. The ultra-supercritical pulverized coal power plant with and without CCS was assessed. Authors have used levelized cost of electricity (LCOE) assessment for showing the viability of investment in the power plant. In the case without the CCS, the calculated LCOE was $57.25 € / \mathrm{MW} \mathrm{h}$, while in the case with installed CCS the LCOE was $92.42 € / \mathrm{MW} \mathrm{h}$. Assumed carbon price was $10 € / \mathrm{tCO}_{2}$, while the assumed running times of the power plant were $7200 \mathrm{~h}$ and $7600 \mathrm{~h}$. In the sensitivity analysis authors have shown that reduction in availability of $10 \%$ can increase the LCOE cost for up to $6 € / \mathrm{MW} \mathrm{h}$. It would be even more interesting to see the calculated LCOE with the running time of around $5000 \mathrm{~h}$ ( $35 \%$ reduction in availability), as it can be assumed that the LCOE result would be even worse.

The latter finding is crucial here. The electricity price is formed on market according to the supply and demand. Supply curve is built according to merit order of every power plant. Power plants bid their offers according to variable costs of electricity generation and in the case of PVs, wind energy, run-of-river hydro and CSP this cost is zero. Thus, power plant which uses fuel, such as coal, needs to make its offer at some higher price as it least needs to cover the costs of fuel and other variable costs. When there is a lot of electricity production from wind or solar energy, the marginal cost of electricity will be very low, much lower than the cost of electricity generation from coal power plant. This leads to the conclusion that there will be many hours when electricity generation is dominated by wind and solar sources (as shown in Figs. 3 and 4), forcing the coal fired power plants to be shut down in these hours. As a result, coal fired power plants will have much lower number of running hours throughout the year than assumed in [101], which results in economic unfavourable indicators. Although in some countries of SEE the El-spot market still has not been set in place, it is expected that this will happen in the near future and thus, investment in coal power plants, both with or without CCS, will be economic unviable. Because of this reasoning, new coal fired power plant investments should not be considered when planning the future energy system development.

Authors in [102] presented the methodology developed in the RE-SEEties: "Towards resource efficient urban communities in SEE" project, focusing on overview of urban energy and waste management systems of communities in SEE. They suggested integrated, transnational approach to promote RES and energy efficiency measures. The project resulted in many recommendations for successful implementation of energy efficiency measures, increase of public acceptance for RES and waste handling (both recycling and waste-to-energy).

Many recommendations and findings in the mentioned paper coincide with the measures proposed in this paper. Some of these measures are: increase in energy efficiency, waste-to-energy utilization, RES penetration, choosing ambitious goals, transnational (regional) cooperation and integrated approach in transformation of energy system towards a low-carbon one. It can be concluded that both papers strive towards the sustainable society and are mutually complementing. This paper deals more with the technical side of the problem and the pathway towards reaching the 100\% renewable energy system, while [102] puts more emphasize on the implementation of specific measures and recommendations for cooperation between different stakeholders.

Thus, compared to the previous papers with case studies being done in the region of SEE, it is shown in this paper that integrated and holistic approach to the whole energy system can open the space for the detection of additional benefits for the system which can improve the system from technical point of view. Furthermore, a holistic approach when adopting certain energy efficiency measures or measures on promotion of certain technologies on the supply side of the energy system can reduce the total annual socio-economic costs of the energy system.

Technical calculations are just the stepping stone but joint energy planning can have more benefits as in the case of electricity and gas transmissions system planning. To have a common policy, such as achieving zero carbon systems for SEE, can have benefits in terms of security of investments, economies of scale, joint public private partnerships and technology development, especially 
Table 7

Comparison of results obtained in sensitivity analysis.

\begin{tabular}{lll}
\hline & 2050 & 2050 \\
& $50 \%$ less hydro & \\
\hline PES [TWh] & 748.4 & 702.86 \\
$\mathrm{CO}_{2}$ emissions [Mt] & 0 & 0 \\
CEEP [TWh] & 13.85 & 15.64 \\
Biomass Consumption [PJ] & 1044 & 726 \\
Total annual socio-economic cost [MEUR] & 47,900 & 44,415 \\
\hline
\end{tabular}

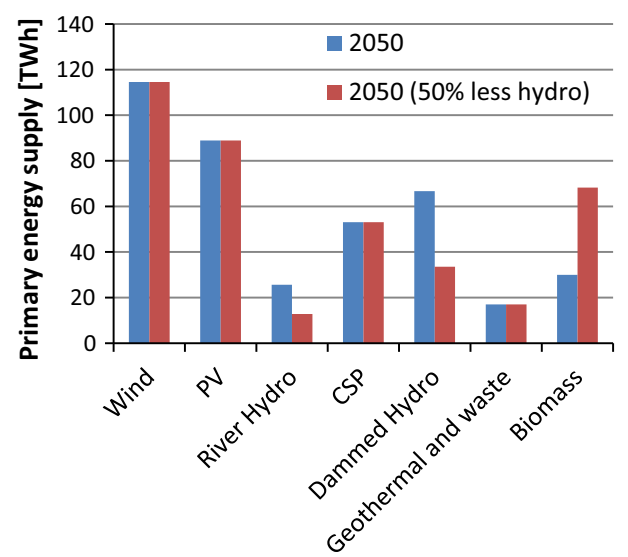

Fig. 5. Difference in electricity generation during sensitivity analysis.

towards sustainable energy technologies such as ecologically harmless hydropower plants. Al these benefits need to be further elaborated and addressed in the further research.

\section{Sensitivity analysis}

As shown in [67] for the case of Croatia, hydro power plants production can deviate from the mean value for up to $47 \%$. Although in the last decade the highest extremes were showing during the wet years, the sensitivity analysis will be carried out assuming that the extreme will show up during the dry year. As similar conditions appear in all the countries of the region, a sensitivity analysis with $50 \%$ less production of hydro power plants has been carried out.

As it can be seen from Table 7, during the extremely dry year biomass consumption can become unsustainable. Moreover, during the dry year additional space for renewable technology such as wind can occur. Increase in biomass consumption during the dry year equals to a significant $43.8 \%$. In Fig. 5 , it can be seen that there is no capacity in other renewable technologies and biomass driven plants need to take over all the missing hydro production.

Thus, in order to achieve the sustainable use of biomass on projected extremely dry year, an additional capacity of renewable technologies should be installed. However, the projected dry year is a real extreme and the 'savings' in biomass during the wet year can cover the unsustainable use of biomass during the dry year. This reasoning stems from the research carried out for the case of Norway in which was shown that the wet years occur three times more frequently compared to dry year [40].

Moreover, long-term melt-down of glaciers in Austrian Alps can cause increased flow in downstream rivers, which can increase hydropower potential during the melting season from May to October as shown in [103]. However, ever increasing melting rate of snow can reduce its ability to serve as accumulation, which can cause floods and more intermittent production of hydro power plants. By this example it can be seen that climate modelling is crucial in planning of future energy systems.

\section{Conclusion}

In this paper, energy system of SEE has been analysed. It was clearly shown that $100 \%$ renewable energy system of the whole region is possible by taking many steps in different sectors during the transformation phase to zero carbon society. Furthermore, to achieve $100 \%$ renewable energy system, and in the same time sustainable in terms of biomass consumption, integration between different sectors of energy systems is needed in order to increase overall efficiency of the system. By integrating energy systems, carefully interacting within them and investing in heating energy storage, serious savings in primary energy consumption can be achieved. It is of great importance to maximally utilize cheap gas and heating energy storage (compared to electrical one), as well as electrical storage in vehicles, following V2G concept, in order to have the attractive system from economic point of view, too. Following these steps, a developed renewable energy system of the SEE consumed 702.86 TWh of primary energy, 50.7\% less compared to the year 2012. Furthermore, the system reached zerocarbon emissions in a technically viable way as the CEEP remained below the $5 \%$, i.e. it was $4.4 \%$. The modelled power system is robust as neither of generation technologies exceeds $30 \%$ of the total generation mix. Among them, wind and PV are dominant technologies with the generation shares of $28.9 \%$ and $22.5 \%$, respectively. Installed thermal capacity is reduced from 37.1 to $24.7 \mathrm{GWs}$, its yearly load factor is $14.8 \%$ and they are completely driven by biomass. The load factor of these plants does not need to be high as their use in the future system is only to cover the periods when there are no fuel-free generation options available. Finally, integrated regional energy system of the future has $30.5 \%$ lower total yearly socio-economic costs compared to the current system.

In order to consume biomass in a sustainable way, some type of synthetic fuel is needed. In this paper, the chosen technology was hydrogenation of biomass, which increases the efficiency in the transportation sector and reduces biomass consumption compared to the usage of biofuels. For the case of the SEE the consumption of biomass (726 PJ) is just under its sustainable potential (726.74 PJ). This is an important improvement compared to the previous work in which $1670 \mathrm{PJ}$ of biomass consumption was assumed for the same region [34].

Sensitivity analysis showed that the system could face with unsustainable use of biomass on extremely dry year. However, this should be covered by 'savings' in biomass during the wet years. Nevertheless, this leads to the conclusion that an emphasis should be put on climate modelling in the future research.

Finally, although it is shown that it is possible, many serious steps, coordinated on a large scale, have to be made in order to gradually switch the SEE energy system from fossil dependent one to $100 \%$ renewable one.

\section{Acknowledgments}

The authors would like to acknowledge International Centre for Sustainable Development of Energy, Water and Environment Systems (SDEWES Centre) for providing the framework for these calculations and French Embassy in Croatia for supporting awareness and debate in Central and South Eastern Europe on climate change.

The contribution from EU projects FP7: S2Biom and DISKNET, IEE: STRATEGO, Danish innovation fund project 4DH and CITIES project funded by Danish Strategic Research Council have been greatly acknowledged. 


\section{References}

[1] Karova R. Regional electricity markets in Europe: focus on the energy community. Util Policy 2011;19:80-6. http://dx.doi.org/10.1016/i. jup. 2010.10.001.

[2] Creti A, Fumagalli E, Fumagalli E. Integration of electricity markets in Europe: relevant issues for Italy. Energy Policy 2010;38:6966-76. http://dx.doi.org/ 10.1016/j.enpol.2010.07.013.

[3] Kozioł J, Mendecka B. Evaluation of economic, energy-environmental and sociological effects of substituting non-renewable energy with renewable energy sources. JSDEWES 2015;3:333-43.

[4] Worldmeters. www.worldometers.info/world-population/population-bycountry/ [accessed October 3, 2015].

[5] European Commission - Eurostat. ec.europa.eu/eurostat/statistics-explained index.php/Population_structure_and_ageing [accessed February 26, 2016].

[6] The World Bank. data.worldbank.org/indicator/NY.GDP.PCAP.CD/countries/ EU? display=default [accessed October 4, 2015].

[7] Graphatlas. www.graphatlas.com/europe_map_climate.png [accessed October 4, 2015].

[8] Gnansounou E, Bayem H, Bednyagin D, Dong J. Strategies for regiona integration of electricity supply in West Africa. Energy Policy 2007;35:4142-53. http://dx.doi.org/10.1016/j.enpol.2007.02.023.

[9] Gnansounou E, Dong J. Opportunity for inter-regional integration of electricity markets: the case of Shandong and Shanghai in East China. Energy Policy 2004;32:1737-51. http://dx.doi.org/10.1016/S0301-4215(03) $\underline{00164-2}$.

[10] Srivastava L, Misra N. Promoting regional energy co-operation in South Asia. Energy Policy 2007;35:3360-8. http://dx.doi.org/10.1016/i enpol.2006.11.017.

[11] De Nooij M. Social cost-benefit analysis of electricity interconnector investment: a critical appraisal. Energy Policy 2011;39:3096-105. http://dx doi.org/10.1016/i.enpol.2011.02.049.

[12] Lynch MÁ, Tol RSJ, O'Malley MJ. Optimal interconnection and renewable targets for north-west Europe. Energy Policy 2012;51:605-17. http://dx.doi. org/10.1016/i.enpol.2012.09.002.

[13] Aslani A, Naaranoja M, Wong K-FV. Strategic analysis of diffusion of renewable energy in the Nordic countries. Renew Sustain Energy Rev 2013;22:497-505. http://dx.doi.org/10.1016/i.rser.2013.01.060.

[14] Rasmussen MG, Andresen GB, Greiner M. Storage and balancing synergies in a fully or highly renewable pan-European power system. Energy Policy 2012;51:642-51. http://dx.doi.org/10.1016/j.enpol.2012.09.009.

[15] European Renewable Energy Council. RE-thinking 2050. A 100\% renewable energy vision for the European Union. Brussels, Belgium; 2010.

[16] Li G, Bie Z, Kou Y, Jiang J, Bettinelli M. Reliability evaluation of integrated energy systems based on smart agent communication. Appl Energy 2016;167:397-406.

[17] Li J, Fang J, Zeng Q, Chen Z. Optimal operation of the integrated electrical and heating systems to accommodate the intermittent renewable sources. App. Energy 2016;167:244-54.

[18] Hooper E, Medvedev A. Electrifying integration: electricity production and the South East Europe regional energy market. Util Policy 2009;17:24-33. http://dx.doi.org/10.1016/i.jup.2008.02.009.

[19] Kristiansen T. Cross-border transmission capacity allocation mechanisms in South East Europe. Energy Policy 2007;35:4611-22. http://dx.doi.org/ 10.1016/i.enpol.2007.03.020.

[20] Pollitt M. Evaluating the evidence on electricity reform: lessons for the South East Europe (SEE) market. Util Policy 2009;17:13-23. http://dx.doi.org 10.1016/j.jup.2008.02.006.

[21] Deitz L, Stirton L, Wright K. South East Europe's electricity sector: attractions, obstacles and challenges of Europeanisation. Util Policy 2009;17:4-12. http:/ dx.doi.org/10.1016/i.jup.2008.03.001.

[22] Vailati R. Electricity transmission in the energy community of South East Europe. Util Policy 2009;17:34-42. http://dx.doi.org/10.1016/i jup.2008.03.005

[23] European Council. Conclusions on 2030 climate and energy policy framework. Zhurnal Eksp I Teor Fiz 2014;2014:1-10.

[24] Bhattacharya M, Paramati SR, Ozturk I, Bhattacharya S. The effect of renewable energy consumption on economic growth: evidence from top 38 countries. Appl Energy 2016;162:733-41. http://dx.doi.org/10.1016/i apenergy.2015.10.104

[25] Mathiesen BV, Lund H, Connolly D, Wenzel H, Østergaard Pa, Möller B, et al. Smart energy systems for coherent 100\% renewable energy and transport solutions. Appl Energy 2015;145:139-54. http://dx.doi.org/10.1016/i. apenergy.2015.01.07

[26] Krajačić G, Duić N, Zmijarević Z, Mathiesen BV, Vučinić AA, da Graça Carvalho M. Planning for a $100 \%$ independent energy system based on smart energy storage for integration of renewables and $\mathrm{CO}_{2}$ emissions reduction. App Therm Eng 2011;31:2073-83. http://dx.doi.org/10.1016/i. applthermaleng.2011.03.014.

[27] Ćosić B, Krajačić G, Duić N. A 100\% renewable energy system in the year 2050 the case of Macedonia. Energy 2012;48:80-7. http://dx.doi.org/10.1016/i. energy.2012.06.078.

[28] Perković L, Silva P, Ban M, Kranjčević N, Duić N. Harvesting high altitude wind energy for power production: the concept based on Magnus' effect. App Energy 2013;101:151-60. http://dx.doi.org/10.1016/i.apenergy.2012.06.061.
[29] Ban M, Perković L, Duić N, Penedo R. Estimating the spatial distribution of high altitude wind energy potential in Southeast Europe. Energy 2013;57:24-9. http://dx.doi.org/10.1016/i.energy.2012.12.045.

[30] Đukan M, Aralica Z. Analysing a bottom-up methodology for developing communal biogas plants in Croatia. JSDEWES 2015;3:359-71.

[31] Brouwer AS, van den Broek M, Zappa W, Turkenburg WC, Faaij A. Least-cost options for integrating intermittent renewables in low-carbon power systems. Appl Energy 2016;161:48-74. http://dx.doi.org/10.1016/j. apenergy.2015.09.090.

[32] Vidal-Amaro JJ, Stergaard PA, Sheinbaum-Pardo C. Optimal energy mix for transitioning from fossil fuels to renewable energy sources - the case of the Mexican electricity system. Appl Energy 2015;150:80-96. http://dx.doi.org/ 10.1016/i.apenergy.2015.03.13.

[33] Kumar S. Assessment of renewables for energy security and carbon mitigation in Southeast Asia: the case of Indonesia and Thailand. Appl Energy 2016;163:63-70. http://dx.doi.org/10.1016/i.apenergy.2015.11.019.

[34] Ćosić B, Maršić T, Krajačić G, Markovska N, Batas Bjelic I, Gota D-I, et al. The effect of regionally integrated energy systems on $\mathrm{CO}_{2}$ emissions reduction and wind integration: the case of South East Europe. In: 6th Int Conf Sustain Energy Environ Protect; 2013.

[35] ACCESS. Project title: Accelerated penetration of small-scale biomass and solar. Deliverable No: D13. Maps and databases on the biomass potential; 2009. p. 40.

[36] Domac J, Panoutsou C. Overview of the South-East Europe bioenergy potential; 2010.

[37] Sahiti N, Sfishta A. Forest biomass characteristics in Kosovo. Sci Efforts Rusenskia Univ; 2014. p. 53.

[38] Domjan S. Country study on political framework; 2009.

[39] Reports JS and P. Assessment of the European potential for pumped hydropower energy storage. Luxembourg; 2013.

[40] EnergyPLAN n.d. http://www.energyplan.eu/smartenergysystems/ [accessed October 4, 2015].

[41] Connolly D, Lund H, Mathiesen BV, Leahy M. A review of computer tools for analysing the integration of renewable energy into various energy systems.

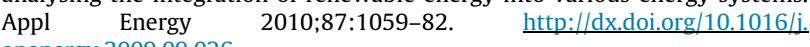
apenergy.2009.09.026.

[42] European Renewable Energy Council. Energy [r]evolution - a sustainable world energy outlook; 2007. p. 1-96.

[43] Teske S, Schaefer O, Zervos A, Beranek J, Tunmore S. Energy [R]evolution: a sustainable global energy outlook; 2008.

[44] Erec \& Greenpeace. Energy revolution: a sustainable world energy outlook, 3rd ed.; 2010

[45] Teske S. Energy [R]Evolution - a sustainable world energy outlook; 2012.

[46] Krajačić G, Duić N, Carvalho MDG. How to achieve a 100\% RES electricity supply for Portugal? Appl Energy 2011;88:508-17. http://dx.doi.org/10.1016/ j.apenergy.2010.09.006.

47] Groenewoud R. Energy self-sufficient neighborhoods in the Netherlands: technical framework on the energy storage \& land usage requirement for intermittent renewable energy systems. Master thesis at Faculty of Geosciences; 2013.

[48] Porubova J, Bazbauers G. Analysis of long-term plan for energy supply system for Latvia that is $100 \%$ based on the use of local energy resources. Sci J Riga Tech Univ Environ Clim Technol 2010;4:82-90. http://dx.doi.org/10.2478/ v10145-010-0022-7.

[49] Connolly D, Lund H, Mathiesen BV, Leahy M. The first step towards a $100 \%$ renewable energy-system for Ireland. Appl Energy 2011;88:502-7. http://dx. doi.org/10.1016/j.apenergy.2010.03.006.

[50] Lund H, Mathiesen BV. Energy system analysis of $100 \%$ renewable energy systems-the case of Denmark in years 2030 and 2050. Energy 2009;34:524-31. http://dx.doi.org/10.1016/j.energy.2008.04.003.

[51] Lund H, Østergaard PA, Stadler I. Towards 100\% renewable energy systems. Appl Energy 2011;88:419-21. $\quad$ http://dx.doi.org/10.1016/i. apenergy.2010.10.013.

[52] Connolly D, Nielsen S, Persson U. Heat Roadmap Europe 2050. Second prestudy for the EU27; 2013.

[53] Lund $\mathrm{H}$. EnergyPLAN documentation version 11.4; 2014

[54] Dai H, Xie X, Xie Y, Liu J, Masui T. Green growth: the economic impacts of large-scale renewable energy development in China. Appl Energy 2016;162:435-49. http://dx.doi.org/10.1016/i.apenergy.2015.10.049.

[55] Zvingilaite E. Human health-related externalities in energy system modelling the case of the Danish heat and power sector. Appl Energy 2011;88:535-44. http://dx.doi.org/10.1016/i.apenergy.2010.08.007.

[56] Shih Y-H, Tseng C-H. Cost-benefit analysis of sustainable energy development using life-cycle co-benefits assessment and the system dynamics approach. Appl Energy 2014;119:57-66. $\quad \underline{\text { http://dx.doi.org/10.1016/i. }}$ apenergy.2013.12.031.

[57] Dominković DF. The role of large scale heat pumps in future energy systems. University of Zagreb; 2015.

[58] International Energy Agency n.d. http://www.iea.org/ [accessed September 10, 2015]

[59] European Network of Transmission System Operators for Electricity n.d. www.entsoe.eu [accessed September 10, 2015].

[60] Weather Underground. www.wunderground.com/ [accessed September 10 2015]

[61] Durkalić M, Change SEE, Lee F, Berkeley UC, Hrašovec I. South East Europe 2050 energy model; 2015. 
[62] Albanian Energy Regulator (ERE). Annual report - albanian energy sector and the ERE activity for 2009; 2009 .

[63] Bosnia and Herzegovina. Statement on security of energy supply of Bosnia and Herzegovina; 2013.

[64] Energy Sector Study in B\&H 2008; 2008.

[65] Eurostat. Energy, transport and environment indicators. Luxembourg; 2011 [ISBN 978-92-79-16303-6].

[66] EAD Bulgarian Energy Holding. Annual consolidated management report independent auditor's report consolidated financial statements Bulgarian energy holding EAD; 2013.

[67] Ministry of Economy. Energy in Croatia 2012. Zagreb; 2013.

[68] Ćosić B, Markovska N, Krajačić G, Taseska V, Duić N. Environmental and economic aspects of higher RES penetration into Macedonian power system. Appl Therm Eng 2012;43:158-62. http://dx.doi.org/10.1016/j. applthermaleng.2011.10.042.

[69] Energy regulatory agency of the Republic of Montenegro; 2004 [annual report].

[70] Beurskens LWM, Hekkenberg M. Renewable energy projections as published in the national renewable energy action plans of the European Member States; 2011.

[71] European Commission - Directorate-General for Energy and Transport. European energy and transport - trends to 2030 - update 2007. Belgium; 2008.

[72] EuropeAid Co-operation Office. Regional Balkans Infrastructure Study Electricity (REBIS) and Generation Investment Study (GIS). Brussels, Belgium; 2004.

[73] Slovenian Energy Agency. Report on the energy sector in Slovenia for 2012. Slovenia; 2013.

[74] DHInfrastructure consulting firm reviewed by World Bank. Background paper: development and evaluation of power supply options for Kosovo; 2011.

[75] European Commission. Energy Roadmap 2050 impact assessment, Part 2/2: accompanying the document Energy Roadmap 2050. Technology; 2011. p. 1114.

[76] Dominković DF, Ćosić B, Medić Z Bačelić, Duić N. A hybrid optimization model of biomass trigeneration system combined with pit thermal energy storage. Energy Convers Manag 2015;104:90-9. http://dx.doi.org/10.1016/i enconman.2015.03.056.

[77] Mathiesen BV, Lund H, Karlsson K. 100\% Renewable energy systems, climate mitigation and economic growth. Appl Energy 2011;88:488-501. http://dx. doi.org/10.1016/i.apenergy.2010.03.001.

[78] Zhang N, Smith R, Bulatov I, Klemeš JJ. Sustaining high energy efficiency in existing processes with advanced process integration technology. Appl Energy 2013;101:26-32. http://dx.doi.org/10.1016/i.apenergy.2012.02.037.

[79] IEA-ETSAP, IRENA. Solar thermal world n.d. http://www.solarthermalworld. org/sites/gstec/files/news/file/2015-02-27/irena-solar-heat-for-industrialprocesses_2015.pdf [accessed October 3, 2015].

[80] Eynatten K Von, Langejürgen M, Schibisch DM. Advantages of induction reheating in integrated minimills; 2014. p. 67-74.

[81] Ridjan I, Mathiesen BV, Connolly D, Duić N. The feasibility of synthetic fuels in renewable energy systems. Energy 2013;57:76-84. http://dx.doi.org/ 10.1016/i.energy.2013.01.046.

[82] Van Stappen F, Brose I, Schenkel Y. Direct and indirect land use changes issues in European sustainability initiatives: state-of-the-art, open issues and future developments. Biomass Bioenergy 2011;35:4824-34. http://dx.doi.org/ 10.1016/i.biombioe.2011.07.015.
[83] Woess-Gallasch S, Bird N, Cowie A. Special issue: land use impacts of bioenergy. Selected papers from the IEA Bioenergy Task 38 meetings in Helsinki, 2009 and Brussels, 2010. Biomass Bioenergy 2011;35:4751-2. http://dx.doi.org/10.1016/i.biombioe.2010.12.053.

[84] Eea. Europe's onshore and offshore wind energy potential, vol. 6; 2009. http://dx.doi.org/10.2800/11373.

[85] Hoffschmidt B, Alexopoulos S, Rau C, Sattler J, Anthrakidis A, Boura C, et al. Concentrating solar power. Compr Renew Energy 2012;3:595-636. http://dx. doi.org/10.1016/B978-0-08-087872-0.00319-X.

[86] Deutsche Bank Research. Hydropower in Europe; 2010.

[87] Blarke MB, Dotzauer E. Intermittency-friendly and high-efficiency cogeneration: operational optimisation of cogeneration with compression heat pump, flue gas heat recovery, and intermediate cold storage. Energy 2011;36:6867-78. http://dx.doi.org/10.1016/j.energy.2011.10.008.

[88] Blarke MB. Towards an intermittency-friendly energy system: comparing electric boilers and heat pumps in distributed cogeneration. Appl Energy 2012;91:349-65. http://dx.doi.org/10.1016/j.apenergy.2011.09.038.

[89] Mathiesen BV, Blarke MB, Hansen K, Connolly D. The role of large-scale heat pumps for short term integration of renewable energy; 2011.

[90] PlanEnergi. Strategisk energiplan for Sønderborg: Sønderborg energisystem 2029. Sønderborg; 2014.

[91] Božičević D. Building seasonal heat storage of $750 \mathrm{MW} \mathrm{h}$ and capacity of $150 \mathrm{MW}$ in TE-TO Zagreb. In: 11th Int symp power process plants 6th Int FORUM renew energy sour. Rovinj; 2014.

[92] Schmidt T, Miedaner O. Solar district heating guidelines; 2012.

[93] Energinet.dk. Technology data for energy plants; 2012 [ISBN: 978-87-7844940-5].

[94] Production E, Use D. Geothermal utilization in Europe; 2008.

[95] Battocletti L, Lawrence B, Associates. Geothermal resources in the Balkans; 2001 [INEEL/EXT-2001-677INEEL/EXT-2001-677].

[96] Battocletti L, Lawrence B, Associates. Geothermal resources in Eastern Europe; 2001.

[97] Bódis K, Monforti F, Szabó S. Could Europe have more mini hydro sites? A suitability analysis based on continentally harmonized geographical and hydrological data. Renew Sustain Energy Rev 2014;37:794-808. http://dx doi.org/10.1016/i.rser.2014.05.071.

[98] Centre for Renewable Energy Sources and Saving. Sector study on biomassbased heating in the Western Balkans; 2015.

[99] Brown T, Schierhorn P, Tr E, Ackermann T, Gmbh E. Optimising the European transmission system for 77\% renewables by $2030 ; 2011$. http://dx.doi.org/10 1049/iet-rpg.2015.0135.

[100] Pukšec T. Influence of energy policy on long term energy demand planning. University of Zagreb; 2015.

[101] Višković A, Franki V, Valentić V. CCS (carbon capture and storage) investment possibility in South East Europe: a case study for Croatia. Energy 2014;70:325-37. http://dx.doi.org/10.1016/j.energy.2014.04.007.

[102] Salvia M, Di LeoS, Nakos C, Maras H, Panevski S, Fülöp O, et al Creating sustainable and resource efficient future: a methodological toolkit for municipalities. Renew Sustain Energy Rev 2015;50:480-96. http://dx.doi org/10.1016/i.rser.2015.05.027.

[103] Lambrecht A, Mayer C. Temporal variability of the non-steady contribution from glaciers to water discharge in western Austria. J Hydrol 2009;376:353-61. http://dx.doi.org/10.1016/i.jhydrol.2009.07.045. 